\title{
Diversity and Length-Weight relationships of Blenniid Species (Actinopterygii, Blenniidae) from Mediterranean Brackish Waters in Turkey
}

\author{
Deniz İnnal ${ }^{1}$ (D)
}

Cite this article as: Innal, D. (2019). Diversity and length-weight relationships of Blenniid Species (Actinopterygii, Blenniidae) from Mediterranean Brackish Waters in Turkey. Aquatic Sciences and Engineering, 34(3), 96-102.

ORCID IDs of the authors: D.i.: 0000-0002-1686-0959

'Burdur Mehmet Akif Ersoy University, Department of Biology, Burdur, Turkey

Submitted:

31.05.2019

Revision Requested

11.07.2019

Last Revision Received

07.08.2019

Accepted:

07.08.2019

Online published:

05.09.2019

Correspondence:

Deniz İnnal

E-mail:

innald@yahoo.com

(C) Copyright 2019 by Aquatic

Sciences and Engineering

Available online at

https://dergipark.org.tr/ase

\begin{abstract}
This study aims to determine the species composition and range of Mediterranean Blennies (Actinopterygii, Blenniidae) occurring in river estuaries and lagoon systems of the Mediterranean coast of Turkey, and to characterise the length-weight relationship of the specimens. A total of 15 sites were surveyed from November 2014 to June 2017. A total of 210 individuals representing 3 fish species (Rusty blenny-Parablennius sanguinolentus, Freshwater blenny-Salaria fluviatilis and Peacock blenny-Salaria pavo) were sampled from five (Beşgöz Creek Estuary, Manavgat River Estuary, Karpuzçay Creek Estuary, Köyceğiz Lagoon Lake and Beymelek Lagoon Lake) of the localities investigated. The high juvenile densities of $S$. fluviatilis in Karpuzçay Creek Estuary and $P$. sanguinolentus in Beşgöz Creek Estuary were observed.

Various threat factors were observed in five different native habitats of Blenny species. The threats on the habitat and the population of the species include the introduction of exotic species, water pollution, and more importantly, the destruction of habitats. Five non-indigenous species (Prussian carp-Carassius gibelio, Eastern mosquitofish-Gambusia holbrooki, Redbelly tilapia-Coptodon zillii, Stone moroko-Pseudorasbora parva and Rainbow trout-Oncorhynchus mykiss) were observed in the sampling sites. In addition to these freshwater species, several lessepsian species (Keeled mullet-Liza carinata, Por's goatfish-Upeneus pori, Goldband goatfish-Upeneus moluccensis, Marbled spinefoot-Siganus rivulatus, Sillago suezensis and Yellowstripe barracuda-Sphyraena chrysotaenia) were observed in the sampling areas.
\end{abstract}

Keywords: Peacock blenny, Freshwater blenny, Rusty blenny, distribution, estuary

\section{INTRODUCTION}

Blenniidae are one of the most abundant fish families inhabiting tropical and subtropical regions. The family consists of 58 genera and 397 species (Nelson, Grande, \& Wilson, 2016). The blennids of the Mediterranean display a remarkable diversity with regard to habitat preferences, feeding habits, and behaviour (Patzner, Gonçalves, \& Hastings, 2009).

Twenty species have been reported in the Eastern Mediterranean with 3 alien species includ- ed. Alien Blenny species were introduced to the Mediterranean-Black Sea Basin from the Suez Canal (Golani, Öztürk, \& Başusta, 2006). As there is a low interest of commercial fishing of this family in the Turkish coast, there is no available data on the catch statistics of this species.

The biological data on the species, however, are scarce and limited to their distribution (Erazi, 1941; Steinitz, 1950; Aksiray, 1987; Çoker, 1996; Taşkavak, Bilecenoglu, Basusta, \& Mater 2000; Bat, Gönlügür Demirci, \& Öztürk 2006; Yılmaz, Barlas, Yorulmaz, \& Özdemir 2006; Bi- 
lecenoğlu, Kaya, Cihangir, \& Çiçek, 2014; Özgür-Özbek, Özkaya, Öztürk, \& Golani, 2014), parasitology (Alaş, Öktener, Iscimen, \& Trilles 2008; Özer, Özkan, Gürkanlı, Yurakhno, \& Çiftçi, 2016) and evolution (Zander, 1972; Almada et al., 2009).

The parameters of the length-weight relationship (LWR) of the fish species are crucial in the fisheries' biology, supplying the information on several aspects of fish population dynamics (Bagenal \& Tesch, 1978). The current knowledge on LWRs for Blennies is limited to six species, namely, Aidablennius sphynx (Özen, Ayyıldız, Öztekin, \& Altın 2009), Blennius ocellaris (Çiçek, Avsar, Yeldan, \& Ozutok, 2006; Sangun, Akamca, \& Akar, 2007; Özaydın, Uçkun, Akalın, Leblebici, \& Tosunoğlu, 2007; İşmen, Özen, Altınağaç, Özekinci, \& Ayaz, 2007; Illkyaz, Metin, Soykan, \& Kınacıgil 2008; Bok et al., 2011; Acarlı, Kara, \& Bayhan 2014; Bilge, Yapıcı, Filiz, \& Cerim, 2014), Salaria pavo (Özen et al., 2009; Bilge et al., 2014), Parablennius sanguinolentus (Keskin \& Gaygusuz, 2010; Kara, Sağlam, Acarlı, \& Cengiz, 2017), Parablennius tentacularis (Keskin \& Gaygusuz, 2010), Salaria fluviatilis (Illhan, Ustaoğlu, \& Berberoğlu 2013; Ergüden, 2016; Kara et al., 2017).

In both temperate and tropical habitats, the coastal lagoons and estuaries play a crucial role in the aspect of ecology and biology of the species (Bruno, Barbini, Diaz De Astarloa, Martos, \& 2013). Status of Blennies fish composition in Brackishwater systems are still poorly understood. The current study aims to update the range and species composition of Blennids occurring in river estuaries and lagoon systems of Mediterranean coast of Turkey, and to characterise the length-weight relationship of specimens.

\section{MATERIALS AND METHODS}

A total of 15 sites (Yelkoma Lagoon Lake, Ceyhan River Estuary, Seyhan River Estuary, Göksu River Estuary, Paradeniz Lagoon Lake, Berdan River Estuary, Sultansuyu Creek Estuary, Hacımusa Creek Estuary, Karpuzçay Creek Estuary, Manavgat River Estuary, Köprüçay River Estuary, Beşgöz Creek Estuary, Kopak Creek Estuary, Beymelek Lagoon Lake and Köyceğiz Lagoon Lake), representing a variety of habitats (including mouths of rivers and creeks, coastal canals of rivers and lagoonal areas), were repeatedly surveyed from November 2014 to June 2017. Details (Type, substrate structure, macrophyte vegetation density, flow regime) of habitats were recorded. Sampling localities are given in the map (Figure 1), and sampling sites and descriptions are given in Table 1 and Table 2.

The ichthyofauna of the systems was sampled using a shore seine net (10 $\mathrm{m}$ long and $2 \mathrm{~m}$ high; $1.2 \times 2 \mathrm{~mm}$ mesh size). Fish species were identified according to Aksiray (1987). The introduced and exotic taxa of the species were identified following Innal \& Erk'akan (2006). At each locality, the general observations on the population and its situation were also made. Specimens were weighed to the nearest $0.01 \mathrm{~g}$ total weight $(\mathrm{W})$ and were measured to the nearest $0.1 \mathrm{~cm}$ in total length (TL). The $a$ and $b$ parameters were calculated by linear regression on the transformed equation: $\log (w)=\log (a)+b \log (L)$. For each species, the slopes of I ength-weight regressions were compared to 3 using student's t-test.

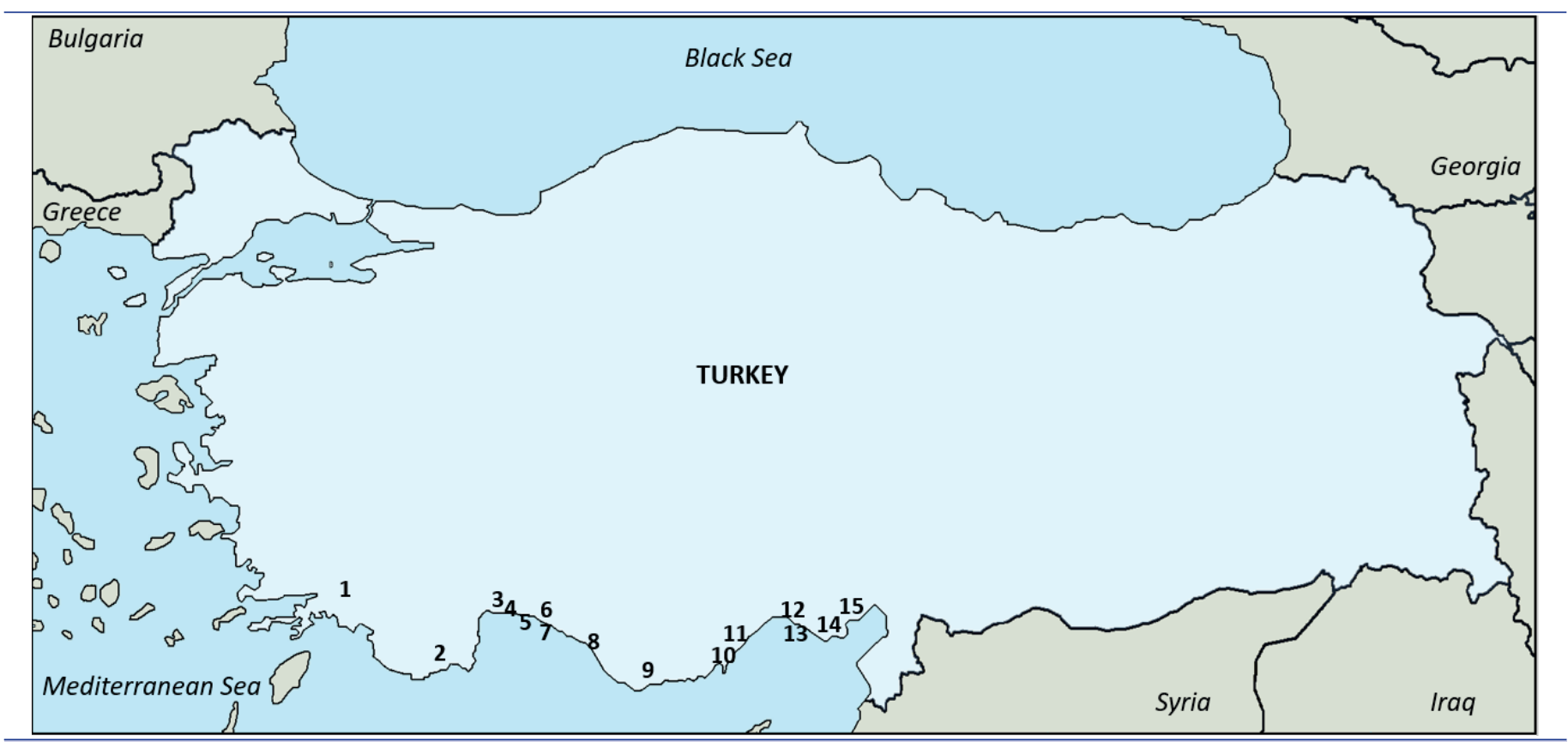

Figure 1. 1-Köyceğiz Lagoon Lake; 2- Beymelek Lagoon Lake; 3- Kopak Creek Estuary; 4- Beşgöz Creek Estuary; 5- Köprüçay River Estuary; 6- Manavgat River Estuary; 7-Karpuzçay Creek Estuary; 8- Hacımusa Creek Estuary; 9- Sultansuyu Creek Estuary; 10- Paradeniz Lagoon Lake; 11- Göksu River Estuary; 12- Berdan River Estuary; 13- Seyhan River Estuary; 14Ceyhan River Estuary; 15- Yelkoma Lagoon Lake. 
Table 1. Sampling sites with its coordinates

\begin{tabular}{llcc}
\hline No & Locality & & Coordinates \\
\hline 1 & Köyceğiz, Köyceğiz (Muğla) & $36^{\circ} 57^{\prime} 30.45^{\prime \prime} \mathrm{N}$ & $28^{\circ} 40^{\prime} 30.46^{\prime \prime} \mathrm{E}$ \\
2 & Beymelek, Demre (Antalya) & $36^{\circ} 16^{\prime} 26.25^{\prime \prime} \mathrm{N}$ & $30^{\circ} 3^{\prime} 15.01^{\prime \prime} \mathrm{E}$ \\
3 & Kopak, Aksu (Antalya) & $36^{\circ} 51^{\prime} 7.27^{\prime \prime} \mathrm{N}$ & $30^{\circ} 52^{\prime} 1.87^{\prime \prime} \mathrm{E}$ \\
4 & Beşgöz, Serik (Antalya) & $36^{\circ} 51^{\prime} 21.89^{\prime \prime} \mathrm{N}$ & $30^{\circ} 56^{\prime} 39.81^{\prime \prime} \mathrm{E}$ \\
5 & Köprüçay, Serik (Antalya) & $36^{\circ} 49^{\prime} 46.82^{\prime \prime} \mathrm{N}$ & $31^{\circ} 10^{\prime} 26.82^{\prime \prime} \mathrm{E}$ \\
6 & Manavgat, Manavgat (Antalya) & $36^{\circ} 44^{\prime} 18.42^{\prime \prime} \mathrm{N}$ & $31^{\circ} 29^{\prime} 38.43^{\prime \prime} \mathrm{E}$ \\
7 & Karpuzçay, Manavgat (Antalya) & $36^{\circ} 42^{\prime} 56.84^{\prime \prime} \mathrm{N}$ & $31^{\circ} 33^{\prime} 00.95^{\prime \prime} \mathrm{E}$ \\
8 & Hacımusa, Gazipaşa (Antalya) & $36^{\circ} 15^{\prime} 45.14^{\prime \prime} \mathrm{N}$ & $32^{\circ} 16^{\prime} 46.54^{\prime \prime} \mathrm{E}$ \\
9 & Sultansuyu, Anamur (Mersin) & $36^{\circ} 2^{\prime} 15.42^{\prime \prime} \mathrm{N}$ & $32^{\circ} 49^{\prime} 8.11^{\prime \prime} \mathrm{E}$ \\
10 & Paradeniz, Silifke (Mersin) & $36^{\circ} 18^{\prime} 27.51^{\prime \prime} \mathrm{N}$ & $34^{\circ} 0^{\prime} 39.00^{\prime \prime} \mathrm{E}$ \\
11 & Göksu, Silifke (Mersin) & $36^{\circ} 17^{\prime} 46.24^{\prime \prime} \mathrm{N}$ & $34^{\circ} 2^{\prime} 42.75^{\prime \prime} \mathrm{E}$ \\
12 & Berdan, Tarsus (Mersin) & $36^{\circ} 44^{\prime} 53.83^{\prime \prime} \mathrm{N}$ & $34^{\circ} 53^{\prime} 29.27^{\prime \prime} \mathrm{E}$ \\
14 & Seyhan, Tarsus (Mersin) & $36^{\circ} 43^{\prime} 44.41^{\prime \prime} \mathrm{N}$ & $34^{\circ} 54^{\prime} 37.71^{\prime \prime} \mathrm{E}$ \\
15 & Ceyhan, Karataş (Adana) & $36^{\circ} 34^{\prime} 10.83^{\prime \prime} \mathrm{N}$ & $35^{\circ} 33^{\prime} 36.15^{\prime \prime} \mathrm{E}$
\end{tabular}

Table 2. Habitat description of sampling sites

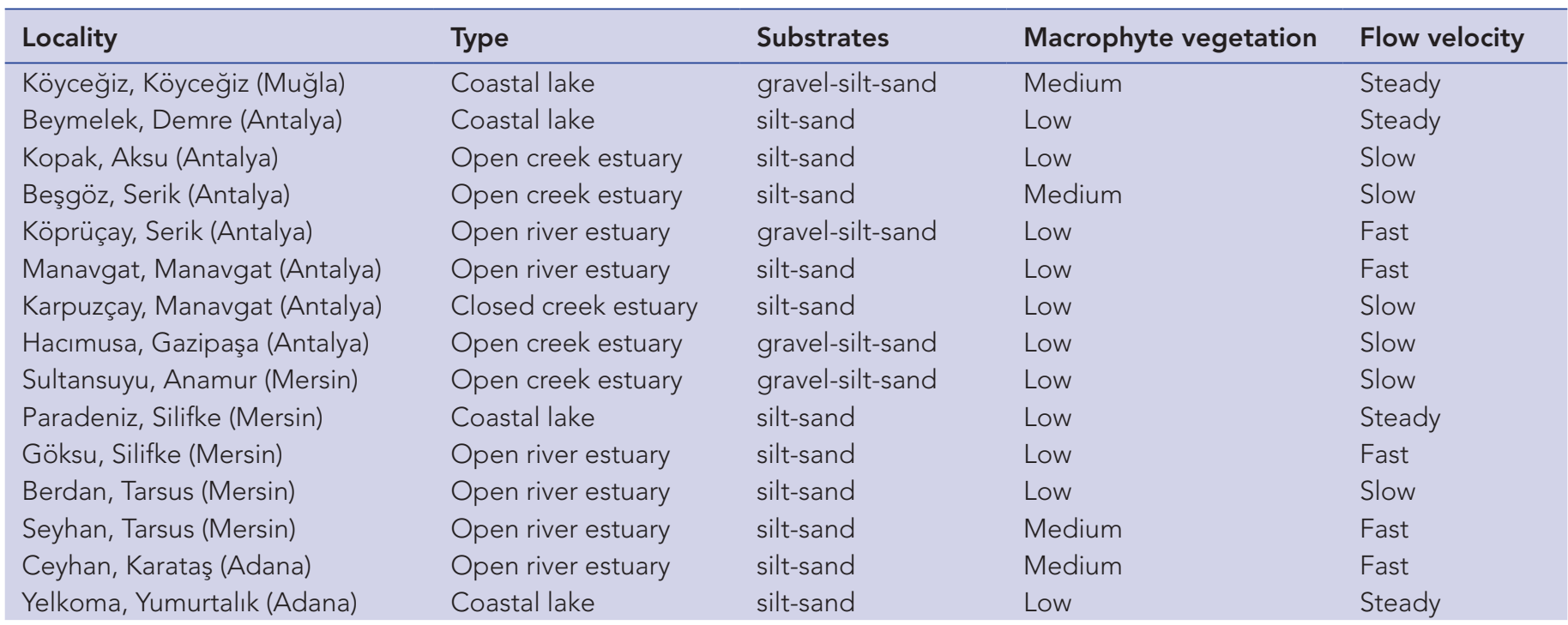

\section{RESULTS AND DISCUSSION}

Brackishwater systems of the Mediterranean encompass diverse habitat types and provide nursery grounds for a number of Blennid species. A total of 210 individuals representing 3 fish species [Parablennius sanguinolentus (Pallas, 1814), Salaria fluviatilis (Asso, 1801) and Salaria pavo (Risso, 1810)] were sampled from five (Beşgöz Creek Estuary, Manavgat River Estuary, Karpuzçay Creek Estuary, Köyceğiz Lagoon Lake and Beymelek Lagoon Lake) of the localities investigated.

One hundred and seven individuals of $P$. sanguinolentus were found at Beşgöz Creek and Manavgat River Estuary, 100 individuals of $S$. fluviatilis were found at three localities (Karpuzçay
Creek Estuary, Manavgat River Estuary and Köyceğiz Lagoon Lake), 3 individuals of S. pavo were found in one locality (Beymelek Lagoon Lake). As can be seen in Table 3, the sample size ranged from 3 individuals for $S$. pavo to 87 for $P$. sanguinolentus.

The high juvenile densities recorded for S. fluviatilis in Karpuzçay Creek Estuary and P. sanguinolentus in Beşgöz Creek Estuary suggest that Beşgöz and Karpuzçay Estuaries provide an important nursery grounds for these species. Nursery areas may be attractive to Blenny species because they provide high food availability and low predation pressure (Martinho et al., 2007; Francis, 2013). Several factors may affect the distribution of Blenny species at the examined stations such as life history, hydrological conditions, predation, prey availability, and anthropogenic impacts. 
Table 3. Locality, sample size and size range $(\mathrm{cm}, \mathrm{TL} ; \mathrm{g}, \mathrm{W})$ of species

\begin{tabular}{lcccc}
\hline Species & Locality & N & TL (Min-Max) & W (Min-Max) \\
\hline S. pavo & Beymelek & 3 & $8.6-9.2$ & $4.0-5.9$ \\
& Karpuzçay & 74 & $2.5-7.5$ & $0.15-4.94$ \\
S. fluviatilis & Köyceğiz & 15 & $2.8-5$ & $0.15-0.85$ \\
& Manavgat & 11 & $2.1-5$ & $0.075-0.99$ \\
& All populations & 100 & $2.1-7.5$ & $0.075-4.94$ \\
P. sanguinolentus & Beşgöz & 87 & $2.1-4.2$ & $0.072-0.83$ \\
& Manavgat & 20 & $1.7-5.0$ & $0.032-0.85$ \\
& All populations & 107 & $1.7-5.0$ & $0.032-0.85$
\end{tabular}

Table 4. Length-weight parameters a and b values of species (Growth pattern; N: negative allometry; P: positive allometry; I: Isometry)

\begin{tabular}{|c|c|c|c|c|c|c|c|}
\hline Species & Locality & a & b & $95 \% \mathrm{Cl}$ of $\mathrm{b}$ & t-test & Growth pattern & $\mathbf{R}^{2}$ \\
\hline S. pavo & Beymelek & & & & & & \\
\hline \multirow[t]{4}{*}{ S. fluviatilis } & Karpuzçay & 0.0095 & 3.077 & $3.0629-3.0943$ & $p<0.05$ & $P$ & 0.99 \\
\hline & Köyceğiz & 0.0082 & 2.869 & 2.8232-2.9133 & $p<0.05$ & $\mathrm{~N}$ & 0.97 \\
\hline & Manavgat & 0.0074 & 2.963 & $2.8996-3.0323$ & $p=0.279$ & । & 0.99 \\
\hline & All populations & 0.0062 & 3.308 & $3.2755-3.3339$ & $p<0.05$ & $P$ & 0.96 \\
\hline \multirow[t]{3}{*}{ P. sanguinolentus } & Beşgöz & 0.0047 & 3.655 & $3.629-3.6728$ & $p<0.05$ & $P$ & 0.96 \\
\hline & Manavgat & 0.0069 & 3.0078 & $2.9347-3.058$ & $p=0.903$ & । & 0.99 \\
\hline & All populations & 0.006 & 3.367 & 3.3379-3.3942 & $\mathrm{p}<0.05$ & $P$ & 0.95 \\
\hline
\end{tabular}

Very little information is available on the ecology of most of the Blenny species, which do not have commercial fishery value. Length-weight parameters $a, b$ and the correlation coefficient values are given in Table 4.

The total length of $2.1-7.5 \mathrm{~cm}$ with the mean value of $4.34 \mathrm{~cm}$ for S. fluviatilis, the total length of $8.6-9.2 \mathrm{~cm}$ with the mean value of $8.93 \mathrm{~cm}$ for $S$. pavo and the total length of $1.7-5.0 \mathrm{~cm}$ with the mean value of $2.82 \mathrm{~cm}$ for $P$. sanguinolentus were recorded. Also, the weight of $0.075-4.94 \mathrm{~g}$ with the mean value of $1.07 \mathrm{~g}, 4.0-5.9$ $\mathrm{g}$ with the mean value of $4.67 \mathrm{~g}$ and $0.032-0.85 \mathrm{~g}$ with the mean value of $0.23 \mathrm{~g}$ for $S$. fluviatilis, S. pavo and P. sanguinolentus were recorded, respectively. Salaria pavo was however, excluded because of the inadequate sample size.

The slope $b$ value of the length-weight relationships for S. fluviatilis from all localities was 3.308 (100 individuals). The slope b value of the length-weight relationships for $P$. sanguinolentus investigating all localities was 3.367 (107 individuals). The correlation coefficient values ranged from $0.95-0.99$. The values of parameter $b$ for the localities evaluated was found to be within the expected range of 2.5-3.5 as described by Froese (2006), with Beşgöz as an exception. The parameter $b$ value for Beşgöz was found to be 3.638. The maximum length of Parablennius sanguinolentus found in the current study was smaller than other studies (Keskin \& Gaygusuz, 2010; Liousia et al., 2012). Outside of $b$ value from its normal range (2.5-3.5) could be due to the small length range (2.1-4.2 cm) of $P$. sanguinolentus, the data were not representative for big size individuals. Manavgat population of $P$. sanguinolentus has an isometric growth type while Beşgöz population has a positive allometric growth type.

Among the populations of S. fluviatilis analyzed, one population (Manavgat River Estuary) showed isometry, two populations (Karpuzçay Creek Estuary and Köyceğiz Lagoon Lake) showed allometry. Of the " $b$ " value for seven populations of $S$. fluviatilis reported by ilhan et al., 2013, among the population analyzed, one population (Doğu Akdeniz) showed negative allometry, five populations (Marmara, Küçük Menderes, Antalya, Seyhan and Ceyhan populations) showed Isometry and one population (Batı Akdeniz) showed positive allometry. Variations of growth types reported by the current study and previous reports may be due to physico-chemical and biological parameters of systems and studied methods (time, sampling equipments, length range, gonadal maturity, sex, preserved techniques).

Although S. fluviatilis in Turkey shows a large distribution in aquatic systems such as coastal lagoons, estuaries and freshwater systems, $P$. sanguinolentus and $S$. pavo are restricted to only marine habitats. However, there has not been sufficient data about threats to the latter two species in previous studies. Threat status of these species are of the least concern (Di Natale et al., $2014 a, b)$.

S. fluviatilis was reported from drainage of the Aeagean, Black Sea and Mediterranean regions of Turkey (Geldiay \& Balık, 1996; Demirsoy, 2002; Bostancı, Darçın, \& Helli, 2016). However, S. fluviatilis was commonly reported in sea level habitats. Alp \& Kara 
Table 5. Alien fish species of localities

\begin{tabular}{|c|c|c|c|c|c|c|c|}
\hline No & Species & Family & Köyceğiz & Beymelek & Beşgöz & Manavgat & Karpuzçay \\
\hline 1 & Salaria pavo & Blenniidae & & $\sqrt{ }$ & & & \\
\hline 3 & Parablennius sanguinolentus & Blenniidae & & & $\sqrt{ }$ & $\sqrt{ }$ & \\
\hline \multicolumn{8}{|c|}{ Alien species } \\
\hline 2 & Carassius gibelio & Cyprinidae & & & $\sqrt{ }$ & $\sqrt{ }$ & \\
\hline 3 & Pseudorasbora parva & Cyprinidae & & & $\sqrt{ }$ & $\sqrt{ }$ & \\
\hline 4 & Liza carinata & Mugilidae & & & $\sqrt{ }$ & $\sqrt{ }$ & \\
\hline 5 & Upeneus moluccensis & Mullidae & & & & $\sqrt{ }$ & \\
\hline 6 & Upeneus pori & Mullidae & & & & $\sqrt{ }$ & \\
\hline 10 & Sillago suezensis & Sillaginidae & & & $\sqrt{ }$ & $\sqrt{ }$ & \\
\hline 11 & Sphyraena chrysotaenia & Sphyraenidae & & & & $\sqrt{ }$ & \\
\hline
\end{tabular}

(2007) reported that this species is present in Turkey from high mountain creeks up to 750 meters. S. fluviatilis is found in Mediterranean freshwater systems with small and localized populations (Vinyoles, Cote, \& De Sostoa, 2002). In Mediterranean habitats in which $S$. fluviatilis occurs, the water pollution, eutrophication, deterioration of the quality of the water, gravel extraction, loss of habitat, the existence of exotic species, and construction of dams and river channelization have affected the survival of this species (Crivelli, 2006; Vinyoles, De Sostoa, Casals, \& Bianco 1991; Ferrito \& Tigano, 1996; Vinyoles \& De sostoa, 2007; Laportea, Bertolo, Berrebi, \& Magnan, 2014).

Five brackishwater systems throughout the Turkish coast have been classified as nurseries for three Blennid fish species (S. fluviatilis, $P$. sanguinolentus and $S$. pavo). The results of this study indicate that Blenny species are threatened and under significant danger from many anthropogenic activities.

Eleven fish species from nine families were identified as being alien to the 5 brackishwater systems surveyed in this study (Table 5). Ten non indigenous species (Gambusia holbrooki, Liza carinata, Upeneus pori, Siganus rivulatus, Sillago suezensis, Oncorhynchus mykiss, Sphyraena chrysotaenia, Carassius gibelio, Upeneus moluccensis and Pseudorasbora parva) were observed in the same habitat with Parablennius sanguinolentus and Salaria fluviatilis in Manavgat River Estuary in the current study.

S. fluviatilis was also observed in Köyceğiz lagoon and Karpuzçay Creek, both of which have been subjected to agricultural activity. Coptodon zillii and Gambusia holbrooki in Köyceğiz Lagoon and Gambusia holbrooki in Karpuzçay Creek shared the same habitats with S. fluviatilis.

Six non indigenous species (Carassius gibelio, Pseudorasbora parva, Liza carinata, Gambusia holbrooki, Siganus rivulatus and Silla- go suezensis) were observed in the same habitat with Parablennius sanguinolentus in Beşgöz Creek Estuary in the current study.

Furthermore, the freshwater supply of Beşgöz Creek and Karpuzçay Creek had greatly decreased in recent years due to agricultural irrigation. Municipal waste waters have been discharged into Beşgöz Creek, Köyceğiz Lagoon and Manavgat River.

\section{CONCLUSIONS}

P. sanguinolentus, S. pavo and S. fluviatilis were collected in five brackishwater systems in the Mediterranean Coast of Turkey (Beşgöz Creek Estuary, Manavgat River Estuary, Karpuzçay Creek Estuary, Köyceğiz Lagoon Lake and Beymelek Lagoon Lake). The high juvenile densities recorded for S. fluviatilis in Karpuzçay Creek Estuary and $P$. sanguinolentus in Beşgöz Creek Estuary suggest that Beşgöz and Karpuzçay Estuaries provide an important nursery grounds for these species. Various threat factors were observed in five different localities which are the habitat of Blennid species.

The current study supplies some fundamental information about the distribution and $L$ ength-weight relationships of brackishwater Blenny species and can be helpful for the future studies in the region.

Acknowledgements: The author thanks Prof. Dr. Robert A. Patzner for his contribution to identify juvenile Parablennius sanguinolentus.

Ethics Committee Approval: This study was carried out in accordance with animal welfare and the ethics of trial. All procedures were performed in accordance with the Law on Veterinary and Medical Activities and National Animal Welfare Act. Therefore ethics approval was not required.

Conflict of Interests: The author declares that there are no conflicts of interest. 
Financial Disclosure: Field studies in Ceyhan River Estuary, Seyhan River Estuary, Göksu River Estuary, Manavgat River Estuary were financially supported by TÜBITAK (Scientific and Technological Research Council of Turkey) under the Project numbered KBAG, 114 Z 259.

\section{REFERENCES}

Acarlı, D., Kara, A., \& Bayhan, B. (2014). Length-weight relations for 29 fish species from Homa Lagoon, Aegean Sea, Turkey. Acta Ichthyologica et Piscatoria, 44(3), 249-257. [CrossRef]

Aksiray, F. (1987). Türkiye deniz baliklari ve tayin anahtarı [Marine fishes of Turkey and a key to species]. Istanbul, Turkey: İstanbul Üniversitesi Rektörlüğü Yayınları.

Alaş, A., Öktener, A., Iscimen, A., \& Trilles, J. P. (2008). New host record, Parablennius sanguinolentus (Teleostei, Perciformes, Blenniidae) for Nerocila bivittata (Crustacea, Isopoda, Cymothoidae). Parasitology Research, 102, 645-646.

Almada, V. C., Robalo, J. I., Levy, A., Freyhof, J., Bernardi, G., \& Doadrio, I. (2009). Phylogenetic analysis of Peri-Mediterranean Blennies of the Genus Salaria: Molecular insights on the colonization of freshwaters. Molecular Phylogenetics and Evolution, 52(2), 424-431. [CrossRef]

Alp, A., \& Kara, C. (2007). Distribution pattern and morphological differences between the sexes of River Blenny, Salaria fluviatilis (Asso, 1801), in the Ceyhan River Basin, Turkey. Turkish Journal of Zoology, $31,113-120$

Bagenal, T. B. \& Tesch, F. W. (1978). Age and growth. In T. Bagebal (Ed.), Methods for assessment of fish production in fresh waters (pp, 101136, 3 rd ed.) Oxford, UK: Blackwell Science Publications.

Bat, L., Gönlügür Demirci, G., \& Öztürk, M. (2006). Occurrence of apletodon dentatusbacescui (Murgoci, 1940) (Gobiesocidae) and Coryphoblennius galerita (Linnaeus, 1758) (Blenniidae) at the Central Black Sea Coast of Turkey. Journal of Black Sea/Mediterranean Environment, 12, 59-65.

Bilecenoğlu, M., Kaya, M., Cihangir, B., \& Çiçek, E. (2014). An updated checklist of the marine fishes of Turkey. Turkish Journal of Zoology, 38(6), 901-929. [CrossRef]

Bilge, G., Yapıcı, S., Filiz, H., \& Cerim, H. (2014). Weight-length relations for 103 fish species from the Southern Aegean Sea, Turkey. Acta Ichthyologica et Piscatoria, 44(3), 263-269. [CrossRef]

Bok, T. D., Gokturk, D., Kahraman, A. E., Alıclı, T. Z., Acun, T., \& Ateş, C. (2011). Length-weight relationships of 34 fish species from the Sea of Marmara, Turkey. Journal of Animal and Veterinary Advances, 10, 3037-3042.

Bostancı, D., Darçın, M., \& Helli, S. (2016). A Study on the investigation of fish fauna of Yalıköy Stream (Ordu). Ordu University Journal of Science and Technology, 6(2), 146-157.

Bruno, D. O., Barbini, S. A., Diaz De Astarloa, J. M., \& Martos, P. (2013). Fish abundance and distribution patterns related to environmental factors in a choked temperate coastal lagoon (Argentina). Brazilian Journal of Oceanography, 61(1), 43-53. [CrossRef]

Crivelli, A. J. (2006). Salaria fluviatilis. The IUCN Red List of Threatened Species 2006: e.T60764A12407160. Retrieved from https://www. iucnredlist.org/species/60764/12407160

Çiçek, E., Avsar, D., Yeldan, H., \& Özutok, M. (2006). Length-weight relationships for 31 teleost fishes caught by bottom trawl net in the Babadillimani Bight (northeastern Mediterranean). Journal of Applied Ichthyology, 22, 290-292. [CrossRef]

Çoker, T. (1996). İzmir Körfezi'nde Blenniidae familyası üyelerinin bolluğu, dağılımı ve morfolojik özellikleri üzerine bir araştırma [A study on the abundance, distribution and morphological characteristics of the members of the Blenniidae family in Izmir Bay]. (Master's thesis, Dokuz Eylül University, Izmır, Turkey).
Demirsoy, A. (2002). Genel zoocoğrafya ve Türkiye zoocoğrafyası, "Hayvan Coğrafyası" 5. Baskı, Meteksan A.Ş. Ankara, 2002.1007 Sayfa

Di Natale, A., Bilecenoglu, M., Bariche, M., Bizsel, C., Massuti, E., Williams, J., \& Craig, M. (2014a). Salaria pavo. The IUCN Red List of Threatened Species 2014: e.T185175A1776635. Retrieved from https://www.iucnredlist.org/species/185175/1776635

Di Natale, A., Bilecenoglu, M., Bariche, M., Bizsel, C., Massuti, E., Williams, J., \& Craig, M. (2014b). Parablennius sanguinolentus. The IUCN Red List of Threatened Species 2014: e. T185193A1779730. Retrieved from https://www.iucnredlist.org/ species/185193/1779730

Erazi, R. A. R. (1941). Les blennidés du Bosphore et de la Mer de Marmara. Revue de la Faculte des Sciences de L'universite D'Istanbul, 6, 118-127.

Ergüden, S. A. (2016). Length-weight relationships for six freshwater fish species from the Seyhan Reservoir (South-Eastern Anatolia, Turkey). Journal of Applied Ichthyology, 32, 141-143. [CrossRef]

Ferrito, V., \& Tigano, C. (1996). Decline of Aphanius fasciatus (Cyprinodontidae) and Salaria fluviatilis (Blenniidae) populations in freshwaters of eastern Sicily, Ichthyological Exploration of Freshwaters, 7(2), 181-184.

Francis, M. P. (2013). Temporal and spatial patterns of habitat use by juveniles of a small coastal shark (Mustelus lenticulatus) in an estuarine nursery. PLoS ONE, 8(2), e57021. [CrossRef]

Froese, R. (2006). Cube law, condition factor and weight-length relationships: History, meta-analysis and recommendations. Journal of Applied Ichthyology, 22, 241-253. [CrossRef]

Geldiay, R., \& Balık, S. (1996). Türkiye tatlısu balıkları (2.bs.) [Freshwater fish Turkey ]. Izmir, Turkey: Ege Üniversitesi Su Ürünleri Fakültesi Yayınları.

Golani, D., Öztürk, B., \& Başusta, N. (2006). Fishes of the Eastern Mediterranean. Istanbul, Turkey: Turkish Marine Research Foundation.

Illhan, A., Ustaoğlu, M. R., \& Berberoğlu, S. (2013). The length-weight relationship of freshwater Blenny, Salaria fluviatilis (Asso, 1801) in 7 drainage basin of Turkey. Ege Journal of Fisheries and Aquatic Sciences, 30(1), 41-43. [CrossRef]

Illkyaz, A. T., Metin, G., Soykan, O., \& Kınacıgil H. T. (2008). Length-weight relationship of 62 fish species from the Central Aegean Sea, Turkey. Journal of Applied Ichthyology, 24, 699-702. [CrossRef]

Innal, D., \& Erk'akan, F. (2006). Effects of exotic and translocated fish species in the inland waters of Turkey. Reviews in Fish Biology and Fisheries, 16, 39-50. [CrossRef]

İşmen, A., Özen, Ö., Altınağaç, U., Özekinci, U., \& Ayaz, A. (2007). Weightlength relationships of 63 fish species in Saros Bay, Turkey. Journal of Applied Ichthyology, 23, 707-708. [CrossRef]

Kara, A., Sağlam, C., Acarlı, D., \& Cengiz, Ö. (2017). Length-weight relationships for 48 fish species of the Gediz Estuary, in Izmir Bay (Central Aegean Sea, Turkey). Journal of the Marine Biological Association of the United Kingdom, 98(4), 1-6. [CrossRef]

Keskin, Ç., \& Gaygusuz, Ö. (2010). Length-weight relationships of fishes in Shallow Waters of Erdek Bay (Sea of Marmara, Turkey). IUFS Journal of Biology, 69(1), 25-32.

Laportea, M., Bertolo, A., Berrebi, P., \& Magnan, P. (2014). Detecting anthropogenic effects on a vulnerable species, the freshwater blenny (Salaria fluviatilis): The importance of considering key ecological variables. Ecological Indicators, 36, 386-391. [CrossRef]

Liousia, V., Batziakas, S., Panagiotou, N., Daouti, I., Koutrakis, E., \& Leonardos, I. D. (2012). Length-weight relations of 22 fish species from the Littoral Zone of the Eastern Ionian Sea, Greece. Acta Ichthyologica et Piscatoria, 42(1), 69-72. [CrossRef]

Martinho, F., Leitao, R., Neto, J. M., Cabral, H. N., Marques, J. C., \& Pardal M. A. (2007). The use of nursery areas by juvenile fish in a temperate estuary, Portugal. Hydrobiologia, 587, 281-290. [CrossRef] 
Nelson, J. S., Grande, T. C. \& Wilson M. V. (2016). Fishes of the world. Hoboken, NJ: John Wiley and Sons. [CrossRef]

Özen, O., Ayyıldız, H., Öztekin, A., \& Altın, A. (2009). Length-weight relationships of 17 less-studied fish species from Çanakkale, Marmara Region of Turkey. Journal of Applied Ichthyology, 25, 238-239. [CrossRef]

Özaydın, O., Uçkun, D., Akalın, S., Leblebici, S., \& Tosunoğlu, Z. (2007). Length-weight relationships of fishes captured from Izmir Bay, Central Aegean Sea. Journal of Applied Ichthyology, 23, 695-696. [CrossRef]

Özer, A., Özkan, H., Gürkanlı, C. T., Yurakhno, V., \& Çiftçi, Y. (2016). Morphology, histology and phylogeny of Henneguya sinova sp. nov. (Myxobolidae: Myxozoa) infecting gills of Parablennius tentacularis in the Black Sea, Turkey. Diseases of Aquatic Organisms, 118, 207-215. [CrossRef]

Özgür-Özbek, E., Özkaya, M., Öztürk, B., \& Golani, D. (2014). First record of the Blenny Parablennius thysanius (Jordan and Seale, 1907) in the Mediterranean. Journal of Black Sea/Mediterranean Environment, 20(1), 53-59.

Patzner, R. A., Gonçalves, E. J., \& Hastings, P. A. (2009). The biology of blennies. Enfield, NH:Science Publishers. [CrossRef]

Sangun, L., Akamca, E., \& Akar, M. (2007). Weight-length relationships for 39 fish species from the North-Eastern Mediterranean Coast of Turkey. Turkish Journal of Fisheries and Aquatic Sciences, 7, 37-40.
Steinitz, H. (1950). Contribution to the knowledge of the Blenniidae of the eastern Mediterranean. III. Revue de la Faculté des Sciences de I'Université d'Istanbul, 15(1), 60-87.

Taşkavak, E., Bilecenoglu, M., Basusta, N., \& Mater, S. (2000). Occurrence of Pteragogous pelycus Randall, 1981 (Teleostei: Labridae) and Petroscirtes ancylodon RÜPPEL, 1838 (Teleostei: Blenniidae) at the Eastern Mediterranean Coast of Turkey, Acta Adriatica, 41(2), 53-58.

Vinyoles, D., De Sostoa, A., Casals, F. \& Bianco, P.G. (1991). The populations of Blennius fluviatilis and its geographical distribution. Bull. Zool. Mus. Univ. Amsterdam, Special Issue (7th Intern. Ichthyol. Congress, Den Haag), 91.

Vinyoles, D., Cote, I. M., \& De Sostoa, A. (2002). Nest orientation patterns in Salaria fluviatilis. Journal of Fish Biology, 61, 405-416. [CrossRef]

Vinyoles, D., \& De Sostoa, A. (2007) Life-history traits of the endanger ed river blennySalaria fluviatilis (Asso) and their implicationsfor conservation. Journal of Fish Biology, 70, 1088-1108. [CrossRef]

Yılmaz, F., Barlas, M., Yorulmaz, B., \& Özdemir, N. (2006). A taxonomical study on the inland water fishes of Muğla. Ege Journal of Fisheries and Aquatic Sciences, 23, 27-30.

Zander, C. D. (1972). Evolution of blennioidei in The Mediterranean Sea. Revue des travaux de l'Institut des pêches maritimes, 37(2), 215-221. 